\title{
Vrijednosti i subjektivno iskustvo majčinstva kao prediktori samopoštovanja, samoefikasnosti i školskoga postignuća (pred)adolescenata
}

\author{
Ina Reić Ercegovac \\ Sveučilište u Splitu, Filozofski fakultet, Split, Hrvatska
}

\begin{abstract}
Sažetak
Teorijski okvir ovoga rada sačinjavaju teorija univerzalnih sadržaja i strukture vrijednosti te model doživljaja roditeljstva kao polazište za istraživanje roditeljskih utjecaja na razvojne ishode adolescenata. Cilj je istraživanja bio ispitati odnos između univerzalnih vrijednosti majki i subjektivnoga doživljaja majčinstva te samopoštovanja, samoefikasnosti i školskoga postignuća (pred)adolescenata. U istraživanju su sudjelovale 234 dijade majka - dijete, a primijenjeni su sljedeći upitnici i skale samoprocjene: upitnici općih podataka za majku i adolescente, Upitnik samoefikasnosti za djecu, Skala samopoštovanja, Upitnik životnih vrijednosti te Skala osjećaja roditeljske kompetentnosti. Rezultati su potvrdili neke očekivane rodne razlike u adolescenata, kao i razlike u vrijednostima majki s obzirom na njihovu dob i razinu obrazovanja. Subjektivna procjena kompetentnosti majki značajno je korelirala s vrijednostima postignuća, moći te trijadom konzervativnih vrijednosti. Provedene regresijske analize pokazale su da se manji dio varijance samopoštovanja, samoefikasnosti i postignuća (pred)adolescenata može pripisati vrijednostima majki, pri čemu su najvažniju ulogu imale upravo konzervativne vrijednosti.
\end{abstract}

Ključne riječi: vrijednosti, roditeljstvo, (pred)adolescencija, samopoštovanje, samoefikasnost, školski uspjeh

\section{Uvod}

Roditeljski je odgoj jedan od najvažnijih čimbenika razvoja tijekom djetinjstva i adolescencije. To je složen i dinamičan proces koji se kontinuirano mijenja, prolazi kroz različite faze i ovisi o nizu uzajamno povezanih čimbenika. Može se reći da roditeljski odgoj ovisi o osobinama obaju roditelja, o njihovim vrijednostima i stavovima, osobnim iskustvima odrastanja, životnim iskustvima te okolinskim čimbenicima. U središtu su interesa ovoga rada doživljaj roditeljstva i životne vrijednosti roditelja kao odrednice razvoja tijekom djetinjstva i adolescencije, a što

Ina Reić Ercegovac, Sveučilište u Splitu, Filozofski fakultet, Poljička cesta 35, 21000 Split, Hrvatska. E-pošta: inareic@ffst.hr 
se očituje u razvojnim ishodima adolescenata, poput samopoštovanja, samoefikasnosti i školskoga postignuća.

Rezultati ranijih istraživanja pokazuju kako dobrobit i samopoštovanje opadaju ulaskom u adolescenciju (Inchley i sur., 2016; Robins i sur., 2002; Robins i Trzesniewski, 2005), slično kao i školsko postignuće (Koludrović i Kalebić Jakupčević, 2017; Reić Ercegovac, Maglica i sur., 2019). To je moguće pripisati normativnim razvojnim promjenama, posebno razvojnim zadacima povezanima $\mathrm{s}$ izgradnjom vlastitoga identiteta (Erikson, 1980), a za što je potrebno testirati dotadašnja uvjerenja i stavove, odvojiti se od roditelja, suprotstaviti se autoritetima i prilagoditi mnogobrojnim promjenama koje adolescencija sa sobom nosi. Ti su procesi nerijetko bolni i zahtjevni za adolescente (Rudan, 2004), a njihov tijek i ishod ovise kako o resursima samoga adolescenta, tako i o podršci roditelja i vršnjaka. Pretpostavlja se da kvalitetne interakcije s članovima obitelji, posebno s roditeljima, mogu doprinijeti uspješnijoj prilagodbi (pred)adolescenata, čemu u prilog govore rezultati istraživanja privrženosti roditeljima (Jiang i sur., 2013; Keresteš i sur., 2019) i kvalitete roditeljstva (Lippold i sur., 2015; Maccoby, 2000; Parent i sur., 2016; Sroufe i sur., 2005).

Ranija istraživanja rodnih razlika u glavnim zavisnim varijablama ovoga istraživanja uglavnom pokazuju da djevojke ostvaruju viši školski uspjeh od mladića (Jokić i Ristić-Dedić, 2010; Koludrović i Kalebić Jakupčević, 2017; Reić Ercegovac i Koludrović, 2010), dok su razlike u samopoštovanju i različitim aspektima samoefikasnosti manje konzistentne. Iako većina rezultata upućuje na više samopoštovanje mladića (Frost i McKelvie, 2004; Quatman i Watson, 2001), u nekim je istraživanja utvrđeno više samopoštovanje djevojaka u odnosu na mladiće srednjoškolske dobi (Musić i sur., 2014). Kad je riječ o samoefikasnosti, ranija istraživanja govore o prednosti djevojaka u području akademske samoefikasnosti (Bacchini i Magliulo, 2003; Musić i sur., 2014; Reić Ercegovac i Koludrović, 2010), premda je jedna metaanaliza istraživanja o akademskoj samoefikasnosti uputila na relativno malu, ali značajnu razliku u korist muškaraca, pri čemu su razlike bile značajne tek od kasne adolescencije nadalje (Huang, 2013). Za razliku od akademske samoefikasnosti, razlike u emocionalnoj ili socijalnoj samoefikasnosti rjeđe su bile predmetom istraživanja. Neki podaci upućuju na zaključak da u tim aspektima nema rodnih razlika (Armum i Chellappan, 2016), dok su neki autori utvrdili višu emocionalnu samoefikasnost kod mladića nego kod djevojaka (Bacchini i Magliulo, 2003), odnosno višu socijalnu samoefikasnost kod djevojaka u odnosu na mladiće (Jenkins i sur., 2002).

S obzirom na važnu ulogu roditelja, fokus je ovoga rada na dvama konceptima iz domene roditeljstva za koje se može pretpostaviti da doprinose samopoštovanju, samoefikasnosti i postignućima od razdoblja predadolescencije do srednje adolescencije, a to su roditeljske vrijednosti i doživljaj roditeljstva, odnosno doživljaj majčinstva jer su u istraživanju sudjelovale samo majke. Iako je uloga očeva važna u cjelokupnome procesu odgoja, majke još uvijek značajno više vremena provode s 
djecom (Altenburger i sur., 2018; Geary, 2000; Parke i sur., 2005) te u većini kultura, uključujući i našu, predstavljaju primarnoga skrbnika.

Teorijski je okvir istraživanja vrijednosti teorija univerzalnih sadržaja i strukture vrijednosti (Schwartz, 1992, 2012) prema kojoj je moguće razlikovati deset motivacijskih tipova vrijednosti koji su sadržajno određeni ciljevima i specifičnim vrijednostima (Ferić, 2007), a koje je moguće sažeti u četiri vrijednosti višega reda. Pritom univerzalizam i dobronamjernost sačinjavaju vrijednost višega reda - vlastito odricanje; moć i postignuće vrijednost vlastitoga probitka; samousmjeravanje i stimulans vrijednost otvorenosti za promjene te tradicija, sigurnost i konformizam vrijednost zadržavanja tradicionalnih odnosa (Schwartz, 2012). Hedonizam kao temeljna vrijednost dijelom je povezan i s vlastitim probitkom i s otvorenošću za promjene (Ferić, 2007). Schwartz (2012) navodi da su mnogobrojna međukulturalna istraživanja u 82 zemlje s heterogenim uzorcima sudionika univerzalno potvrdila razlikovanje deset temeljnih vrijednosti. $\mathrm{S}$ obzirom na ulogu tih vrijednosti $\mathrm{u}$ oblikovanju roditeljskoga doživljaja i roditeljske prakse, autori su pretpostavili da su vrijednosti povezane $\mathrm{s}$ roditeljskim ponašanjima jer zbog različitih vrijednosti roditelji, u odgojnome smislu, stavljaju veći naglasak na određene ciljeve za svoju djecu, pa tako i na određena ponašanja. Također, vodeći se pretpostavkama Kohna (1977) o odnosu socijalnoga statusa, vrijednosti i roditeljstva, neki su autori potvrdili povezanost između sociodemografskih obilježja roditelja, vrijednosti i roditeljske prakse (Aavik i sur., 2006; Luster i sur., 1989; Tudge i sur., 1999). Longitudinalno istraživanje započeto u drugoj polovici prošloga stoljeća u kojemu su sudjelovali tadašnji petogodišnjaci i njihove obitelji pokazalo je da rana iskustva u obitelji oblikuju vrijednosti pojedinaca u odrasloj dobi (Kasser i sur., 2002), neovisno o rodu i socioekonomskome statusu. Specifično, rezultati su pokazali da je uz kontrolu roda i socioekonomskoga statusa restriktivnost roditelja u predškolskoj dobi negativno povezana sa samousmjeravajućim vrijednostima pojedinaca u njihovim odraslim godinama te da je roditeljska toplina u predškolskoj dobi djeteta negativno povezana s vrijednošću sigurnosti u odrasloj dobi. Konačno, isto je istraživanje potvrdilo model Kohna (1977) jer je utvrđen djelomični medijacijski učinak roditeljske restriktivnosti $\mathrm{u}$ odnosu između socioekonomskoga statusa obitelji i vrijednosti konformizma u pojedinaca odrasle dobi. Drugim riječima, povezanost između socioekonomskoga statusa obitelji i vrijednosti pojedinaca odgajanih u tim obiteljima dijelom se mogla objasniti roditeljskom praksom.

Vrijednosti predstavljaju jednu od kategorija implicitnoga roditeljstva ili implicitne roditeljske pedagogije (Ljubetić i sur., 2019) te uz roditeljske kognicije i stavove sačinjavaju osnovu roditeljskoga ponašanja. Stoga se očekuje da roditeljske vrijednosti, oblikujući roditeljsko ponašanje, posredno utječu na razvojne ishode djece. To je u skladu s integrativnim modelom roditeljstva (Darling i Steinberg, 1993) prema kojemu roditeljske vrijednosti i ciljevi neposredno utječu na roditeljske stilove i roditeljska ponašanja, koja pak utječu na razvojne ishode djece. Vrijednosti u kontekstu roditeljstva upućuju na važnost koju roditelji pridaju određenim 
odgojnim ciljevima pa sukladno tomu vrijednosti mogu određivati smjer roditeljskoga ponašanja i oblikovati interakciju na relaciji roditelj - dijete. Istraživanja dosad nisu provjeravala neposredan doprinos univerzalnih vrijednosti roditelja objašnjenju razlika u samopoštovanju, samoefikasnosti i školskome postignuću djece i adolescenata, no s obzirom na podatke o ulozi roditeljskih stilova ili ponašanja $u$ objašnjenju razlika u različitim aspektima samoefikasnosti adolescenata (Martinez i sur., 2020), kao i povezanosti roditeljskih ponašanja sa samopoštovanjem i školskim postignućem ili školskom samoefikasnošću djece (Reić Ercegovac i Koludrović, 2010; Sorić i Vulić Prtorić, 2006), sukladno integrativnomu modelu roditeljstva (Darling i Steinberg, 1993) pretpostavlja se da su za te odnose dijelom odgovorne i roditeljske vrijednosti.

Doživljaj roditeljstva predstavlja subjektivnu procjenu roditelja o tome koliko je uspješan u svojoj roditeljskoj ulozi te koliko je zadovoljan svojim roditeljstvom i odnosom s djetetom. Rezultati ranijih istraživanja na kliničkim i nekliničkim uzorcima djece pokazali su da je doživljaj roditeljstva povezan sa stvarnom roditeljskom praksom i kompetencijama (Coleman i Karraker, 1998; Jones i Prinz, 2005; Sanders i Woolley, 2005; Sevigny i Loutzenhiser, 2010; Teti i Gelfand, 1991), pri čemu viša samoefikasnost i više zadovoljstvo doprinose optimalnomu roditeljskom djelovanju. Budući da je roditeljska praksa značajan prediktor razvojnih ishoda djece na različitim dobnim uzrastima (Granic i Patterson, 2006; Parent i sur., 2016), pretpostavlja se da i doživljaj roditeljstva doprinosi objašnjenju individualnih razlika u psihosocijalnoj prilagodbi djece i adolescenata. Stoga je cilj ovoga istraživanja bio ispitati ulogu vrijednosti i doživljaja roditeljstva majki u objašnjenju individualnih razlika u samopoštovanju, samoefikasnosti i školskome postignuću (pred)adolescenata. Odabrani su kriteriji važni pokazatelji psihosocijalnoga funkcioniranja (pred)adolescenata te predstavljaju zaštitne čimbenike za razvoj socioemocionalnih i ponašajnih poteškoća (Carvajal i sur., 1998; Humphrey i sur., 2004; Kendler i sur., 1998; Lacković Grgin, 1994). Da bi se ostvario navedeni cilj, istraživanjem se pokušalo istražiti razlikuju li se (pred)adolescenti i (pred)adolescentice u samopoštovanju, samoefikasnosti i školskome postignuću; razlikuju li se majke s obzirom na dob i razinu obrazovanja u vrijednostima i doživljaju roditeljstva; jesu li vrijednosti povezane s doživljajem roditeljstva majki; te doprinose li vrijednosti majki i njihov doživljaj roditeljstva objašnjenju samopoštovanja, samoefikasnosti i školskoga postignuća (pred)adolescenata. Polazne pretpostavke istraživanja, temeljene na teorijskim okvirima opisanima $\mathrm{u}$ uvodnome dijelu te rezultatima ranijih istraživanja, uključuju očekivanje o višemu školskom postignuću te višoj akademskoj samoefikasnosti djevojaka u odnosu na mladiće; o povezanosti starije dobi i niže razine obrazovanja majki i vrijednosti zadržavanja tradicionalnih odnosa; te, konačno, o značajnome doprinosu i vrijednosti i doživljaja roditeljstva samopoštovanju, samoefikasnosti i školskomu postignuću (pred)adolescenata. 


\section{Metoda}

\section{Sudionici}

U istraživanju su sudjelovale 234 dijade majka - dijete $(N=468)$, pri čemu su djeca bila učenici od četvrtoga razreda osnovne do trećega razreda srednje škole. Prosječna dob (pred)adolescenata iznosila je $M=14.15$ godina $(S D=2.77)$ uz raspon od 10 do 18 godina. Sudjelovalo je 87 mladića i 147 djevojaka. Prosječna dob majki iznosila je $M=43.66$ ( $S D=5.43$ ) uz raspon od 28 do 59 godina. $S$ obzirom na razinu obrazovanja, samo su dvije majke imale samo osnovnoškolsko obrazovanje, $65 \%$ majki $(n=152)$ srednjoškolsko obrazovanje, nešto više od $10 \%$ majki $(n=24)$ više obrazovanje, $20 \%$ visoko obrazovanje $(n=47)$ te $3.85 \%$ majki $(n=9)$ akademski stupanj magistra ili doktora znanosti. Većina majki $(88 \%)$ svoje je djetinjstvo provela uz oba roditelja.

\section{Instrumenti}

Majke koje su sudjelovale $u$ istraživanju ispunile su Upitnik općih podataka kojim su prikupljeni podaci o dobi, razini obrazovanja i vrsti primarne obitelji (pitanjima zatvorenoga tipa), Upitnik vrijednosti te Skalu osjećaja roditeljske kompetentnosti. (Pred)adolescenti su, uz opće podatke, ispunili i Rosenbergovu skalu samopoštovanja te Upitnik samoefikasnosti za djecu i adolescente.

Upitnik općih podataka za adolescente sastojao se od pitanja zatvorenoga tipa kojima su prikupljeni podaci o spolu, dobi te školskome postignuću (općemu uspjehu na kraju protekle školske godine, uspjehu iz Hrvatskoga jezika i uspjehu iz Matematike).

Upitnik samoefikasnosti za djecu $i$ adolescente (Vulić Prtorić i sur., 2006) namijenjen je ispitivanju samoefikasnosti djece i adolescenata u akademskome ( 8 tvrdnji), emocionalnome (7 tvrdnji) i socijalnom (9 tvrdnji) području. Zadatak je sudionika procijeniti za svaku tvrdnju koliko se ona odnosi na njih na skali procjene od 1 do 5, gdje 1 znači uopće nije točno, a 5 znači potpuno je točno. Provjera strukture upitnika primjenom konfirmatorne faktorske analize pokazala je zadovoljavajuće pristajanje podataka pretpostavljenomu trofaktorskomu modelu (RMSEA $=.06$; hi$\mathrm{kvadrat} / d f=1.97$; GFI $=.85 ; \mathrm{CFI}=.84)$. Stoga su formirana tri ukupna rezultata za tri domene samoefikasnosti, pri čemu viši rezultat upućuje na višu samoefikasnost. Treba napomenuti da je jedino podljestvica socijalne samoefikasnosti imala nešto nižu pouzdanost od očekivane i one utvrđene u ranijim istraživanjima. Deskriptivni parametri ukupnih rezultata za tri domene prikazani su u Tablici 1 .

Rosenbergova skala samopoštovanja (Rosenberg, 1965) jedan je od najčešće korištenih instrumenata za ispitivanje općega samopoštovanja. Sastoji se od 10 tvrdnji, a zadatak je sudionika procijeniti stupanj slaganja sa svakom tvrdnjom zaokruživanjem jedne od pet brojki (1 - uopće se ne slažem; 5 - potpuno se slažem). 
Konfirmatorna faktorska analiza uputila je na zaključak o djelomičnome pristajanju podataka jednofaktorskomu modelu jer je dio parametara pokazao neprikladnost modela $(\mathrm{RMSEA}=.11$; hi-kvadrat $/ d f=3.46$ ), a dio zadovoljavajuću prikladnost $(\mathrm{GFI}=.90 ; \mathrm{CFI}=.90) . \mathrm{S}$ obzirom na visoku pouzdanost, formiran je jedan ukupni rezultat sumiranjem odgovora na svih 10 tvrdnji, pri čemu viši ukupni rezultat upućuje na više samopoštovanje. Deskriptivni parametri ukupnih rezultata prikazani su u Tablici 1.

Upitnik životnih vrijednosti (adaptiran za potrebe istraživanja prema Schwartz, 2012) sastojao se od deset temeljnih vrijednosti, a uz svaku je navedeno nekoliko podvrijednosti (primjerice, za temeljnu vrijednost moći navedene su podvrijednosti socijalni utjecaj, autoritet, bogatstvo). Zadatak je sudionika bio procijeniti na skali od 0 do 8 ( 0 - uopće mi nije važno; 8 - izrazito mi je važno) važnost navedenih vrijednosti kao načela kojima se vode u životu.

Skala osjećaja roditeljske kompetentnosti (Gibaud-Wallston i Wandersman, 1978; Johnson i Mash, 1989) dvofaktorska je skala koja je u izvorniku bila namijenjena roditeljima dojenčadi, a kasnije je adaptirana za primjenu na roditeljima djece školske dobi. Ranije primjene na hrvatskim uzorcima potvrdile su dvofaktorsku strukturu upitnika i zadovoljavajuće psihometrijske značajke (Mandarić Vukušić, 2018; Reić Ercegovac i Penezić, 2012). Skala se sastoji od 17 tvrdnji, a zadatak je sudionika procijeniti na skali od 1 (uopće se ne slažem) do 6 (potpuno se slažem) stupanj slaganja sa svakom tvrdnjom. Konfirmatorna faktorska analiza pokazala je zadovoljavajuće pristajanje podataka modelu $\mathrm{s}$ dva faktora $($ RMSEA $=.08 ;$ hi-kvadrat $/ d f=2.35 ; \mathrm{GFI}=.87 ; \mathrm{CFI}=.86)$ koji mjere samoprocjenu roditeljske kompetentnosti i zadovoljstvo roditeljstvom. Nakon obrnutoga bodovanja negativnih tvrdnji formirana su dva ukupna rezultata sumiranjem odgovora na tvrdnjama koje sačinjavaju pojedini faktor, pri čemu viši rezultat upućuje na višu kompetentnost, odnosno više zadovoljstvo roditeljstvom (Tablica 1.).

\section{Postupak istraživanja i analiza podataka}

Rezultati prikazani u ovome radu dio su većega istraživanja o odnosu roditeljstva i razvojnih ishoda tijekom djetinjstva i adolescencije. Podaci analizirani za potrebe ovoga rada prikupljeni su u suradnji s dvjema osnovnim i dvjema srednjim školama (gimnazijom i četverogodišnjom strukovnom školom) iz urbane sredine. Sudjelovanje u istraživanju bilo je dobrovoljno, a majke koje su željele sudjelovati u istraživanju potpisale su informirani pristanak nakon što im je pojašnjenja svrha istraživanja i zajamčena anonimnost podataka. Učenici su tijekom redovite nastave, uglavnom na satu razrednika, dobili upitnik za sebe i majku te su na oba upitnika upisali jednaku šifru kako bi se podaci mogli upariti za svaku dijadu majka - dijete. Potom su ispunili svoj upitnik tijekom jednoga nastavnog sata, a ispunjeni upitnik za majku naknadno su vratili u školu u omotnici. Ukupno je prikupljeno 468 valjano ispunjenih upitnika, odnosno 234 para upitnika za majku i dijete. Prikupljeni podaci 
analizirani su primjenom statističke aplikacije STATISTICA13. Budući da su parametri asimetričnosti i spljoštenosti za većinu varijabli (izuzev dobronamjernosti) bili unutar raspona od -2 do +2 (Tablica 1.), smatralo se da udovoljavaju uvjetima za primjenu parametrijskih postupaka (Gravetter i Wallnau, 2014) te su korišteni u daljnjim analizama.

\section{Tablica 1.}

Deskriptivna obiljě̌ja korištenih mjera

\begin{tabular}{|c|c|c|c|c|c|}
\hline mjera & Cronbachova $\alpha$ & $M(S D)$ & raspon & asimetričnost & spljoštenost \\
\hline Opći uspjeh & - & $4.13(1.01)$ & $1-5$ & -1.63 & 2.73 \\
\hline Hrvatski jezik & - & $3.76(1.03)$ & $1-5$ & -0.75 & 0.26 \\
\hline Matematika & - & $3.55(1.18)$ & $1-5$ & -0.37 & -0.88 \\
\hline Samopoštovanje & .86 & $31.65(5.80)$ & $11-42$ & -0.89 & 0 \\
\hline $\begin{array}{l}\text { Akademska } \\
\text { samoefikasnost }\end{array}$ & .84 & $28.98(6.75)$ & $9-40$ & -0.58 & 0.05 \\
\hline $\begin{array}{l}\text { Emocionalna } \\
\text { samoefikasnost }\end{array}$ & .77 & $22.86(5.72)$ & $8-35$ & -0.32 & -0.16 \\
\hline $\begin{array}{l}\text { Socijalna } \\
\text { samoefikasnost }\end{array}$ & .68 & $34.50(5.51)$ & $19-45$ & -0.32 & -0.48 \\
\hline Moć & - & $3.01(2.13)$ & $0-8$ & 0.41 & -0.43 \\
\hline Postignuće & - & $5.35(1.96)$ & $0-8$ & -0.27 & -0.63 \\
\hline Hedonizam & - & $3.33(2.43)$ & $0-8$ & 0.27 & -0.93 \\
\hline Stimulans & - & 4.63 (1.99) & $0-8$ & -0.21 & -0.51 \\
\hline Samousmjeravanje & - & $6.64(1.66)$ & $1-8$ & -1.02 & -0.07 \\
\hline Univerzalizam & - & $6.97(1.52)$ & $0-8$ & -1.48 & 1.65 \\
\hline Dobronamjernost & - & $7.77(.69)$ & $4-8$ & -3.69 & 15.38 \\
\hline Tradicija & - & $6.84(1.67)$ & $0-8$ & -1.64 & 2.40 \\
\hline Konformizam & - & $6.94(1.48)$ & $1-8$ & -1.36 & 1.04 \\
\hline Sigurnost & - & $7.13(1.33)$ & $1-8$ & -1.68 & 2.38 \\
\hline $\begin{array}{l}\text { Roditeljska } \\
\text { kompetentnost }\end{array}$ & .78 & $35.64(5.94)$ & $19-48$ & -0.26 & -0.11 \\
\hline $\begin{array}{l}\text { Zadovoljstvo } \\
\text { roditeljstvom }\end{array}$ & .83 & $41.72(7.50)$ & $9-54$ & -0.94 & 1.43 \\
\hline
\end{tabular}

\section{Rezultati}

S ciljem uspoređivanja rezultata (pred)adolescenata $\mathrm{i}$ (pred)adolescentica $\mathrm{u}$ zavisnim varijablama samopoštovanja, samoefikasnosti i postignuća proveden je niz t-testova rezultati kojih su prikazani u Tablici 2.

Razlike su utvrđene u općemu uspjehu i uspjehu iz Hrvatskoga jezika, gdje su djevojke ostvarile bolje rezultate, te u samopoštovanju i emocionalnoj samoefikasnosti, gdje su se uspješnijima procijenili mladići. U akademskoj i socijalnoj samoefikasnosti nisu utvrđene značajne rodne razlike. 


\section{Tablica 2.}

Razlike između (pred)adolescenata i (pred)adolescentica u samopoštovanju, samoefikasnosti te školskome postignuću

\begin{tabular}{lccccc}
\hline & $M_{\check{z}}$ & $S D_{\check{z}}$ & $M_{\mathrm{m}}$ & $S D_{\mathrm{m}}$ & $t$ \\
\hline Opći uspjeh & 4.26 & 0.92 & 3.91 & 1.12 & $2.61^{\text {** }}$ \\
Hrvatski jezik & 3.95 & 0.99 & 3.45 & 1.02 & $3.63^{* *}$ \\
Matematika & 3.62 & 1.12 & 3.43 & 1.26 & 1.21 \\
Samopoštovanje & 3.11 & 0.59 & 3.26 & 0.55 & $-1.99^{*}$ \\
Akademska samoefikasnost & 3.65 & 0.77 & 3.57 & 0.95 & 0.69 \\
Emocionalna samoefikasnost & 3.14 & 0.79 & 3.47 & 0.83 & $-2.99^{* *}$ \\
Socijalna samoefikasnost & 3.79 & 0.62 & 3.90 & 0.61 & -1.28 \\
\hline
\end{tabular}

${ }^{*} p<.05 ;{ }^{* *} p<.01$.

Kako bi se istražilo razlikuju li se majke s obzirom na razinu obrazovanja $\mathrm{u}$ vrijednostima i doživljaju roditeljstva, primijenjene su analize varijance s razinom obrazovanja kao nezavisnom varijablom. Pritom su formirane tri skupine majki jer su samo dvije majke imale završeno samo osnovnoškolsko obrazovanje pa su one izostavljene iz analize, a majke s najvišim stupnjem obrazovanja (magisterij ili doktorat znanosti), kojih je bilo devet, pridružene su skupini visokoobrazovanih majki. Rezultati tih analiza prikazani su u Tablici 3.

\section{Tablica 3.}

Razlike u vrijednostima i doživljaju roditeljstva s obzirom na razinu obrazovanja majki

\begin{tabular}{llllc}
\hline & $M$ š & $M v \check{s}$ & $M v o$ & $F(d f=2,229)$ \\
\hline Moć & 2.85 & 3.31 & 3.22 & 0.96 \\
Postignuće & 5.37 & 5.27 & 5.33 & 0.03 \\
Hedonizam & 3.23 & 3.51 & 3.55 & 0.41 \\
Stimulans & 4.71 & 4.79 & 4.40 & 0.55 \\
Samousmjeravanje & 6.53 & 7.22 & 6.67 & 1.88 \\
Univerzalizam & 6.98 & 6.96 & 7.06 & 0.05 \\
Dobronamjernost & 7.75 & 7.62 & 7.88 & 1.49 \\
Tradicija & 6.99 & 6.38 & 6.65 & 1.95 \\
Konformizam & 7.12 & 6.65 & 6.50 & $4.15^{*}$ \\
Sigurnost & 7.28 & 7.00 & 6.81 & 2.59 \\
Roditeljska & 4.56 & 4.42 & 4.18 & $5.63^{* *}$ \\
kompetentnost & & & & \\
Zadovoljstvo & 4.55 & 4.86 & 4.80 & 2.75 \\
roditeljstvom & & &
\end{tabular}

Napomena: $M \mathrm{sš}$ - srednjoškolsko obrazovanje; $M \mathrm{vš}$ - viša ili preddiplomska razina obrazovanja; $M \mathrm{vo}$ visoka ili diplomska te poslijediplomska razina obrazovanja; ${ }^{*} p<.05 ;{ }^{* *} p<.01$.

Među vrijednostima jedina je razlika utvrđena za konformizam koji su važnijim procijenile majke srednjoškolske razine obrazovanja u odnosu na visokoobrazovane majke. U ostalim vrijednostima razlike s obzirom na razinu obrazovanja majki nisu 
utvrđene. Roditeljska se kompetentnost značajno razlikovala s obzirom na razinu obrazovanja, pri čemu su se majke sa srednjoškolskom razinom obrazovanja procijenile kompetentnijima u roditeljstvu od majki s višom, odnosno visokom razinom obrazovanja čije su procjene roditeljske kompetentnosti najniže.

S obzirom na to da je dob tretirana kao kontinuirana varijabla, izračunani su koeficijenti korelacija između dobi i vrijednosti te doživljaja roditeljstva. Rezultati su pokazali da postoji značajna povezanost između dobi i samousmjeravanja ( $r=$ $-.15 ; p<.05)$ te dobi i konformizma $(r=-.14 ; p<.05)$, pri čemu su korelacije negativne iz čega je moguće zaključiti da su mlađim majkama, u odnosu na starije, navedene vrijednosti važnije. Između ostalih vrijednosti i dobi nisu utvrđene značajne povezanosti. Povezanost između dobi i doživljaja roditeljstva utvrđena je samo za samoprocjenu roditeljske kompetentnosti $(r=-.15 ; p<.05)$, pri čemu su se mlađe majke procijenile kompetentnijima u odnosu na starije.

S ciljem odgovora na treći problem istraživanja provedena je korelacijska analiza između zadovoljstva roditeljstvom i roditeljske kompetentnosti te vrijednosti majki, a rezultati su prikazani u Tablici 4. Majke koje više vrednuju moć, postignuće te tradicionalne vrijednosti procijenile su se kompetentnijima, dok je jedina značajna povezanost sa zadovoljstvom roditeljstvom, i to negativna, utvrđena za hedonizam.

\section{Tablica 4.}

Koeficijenti korelacija između doživljaja roditeljstva i roditeljskih vrijednosti

\begin{tabular}{lcc}
\hline & Zadovoljstvo roditeljstvom & Roditeljska kompetentnost \\
\hline Moć & -.05 & $.16^{*}$ \\
Postignuće & .10 & $.26^{*}$ \\
Hedonizam & $-.16^{*}$ & .08 \\
Stimulans & -.06 & .13 \\
Samousmjeravanje & .11 & .12 \\
Univerzalizam & .10 & .12 \\
Dobronamjernost & .10 & .09 \\
Tradicija & -.05 & $.13^{*}$ \\
Konformizam & -.05 & $.21^{*}$ \\
Sigurnost & .07 & $.15^{*}$ \\
\hline
\end{tabular}
${ }^{*} p<.05$.

Kako bi se odgovorilo na posljednji problem istraživanja i ispitalo doprinose li vrijednosti i doživljaj roditeljstva postignuću, samopoštovanju i samoefikasnosti adolescenata, proveden je niz stupnjevitih regresijskih analiza rezultati kojih su prikazani u Tablici 5. Korištena je metoda forward stepwise zbog većega broja prediktorskih varijabli. U svim su analizama redom uvedene varijable dobi i spola djece, dobi majke, deset životnih vrijednosti majki te samoprocjena roditeljske kompetentnosti i zadovoljstva roditeljstvom majki. Iz Tablice 5. vidljivo je da su značajan prediktorski koeficijent imale uglavnom varijable dobi i spola djece, i to tako da je mlađa dob povezana s boljim uspjehom iz Matematike i višom akademskom samoefikasnošću te 
da je ženski spol prediktivan za bolji školski uspjeh i višu akademsku samoefikasnost, ali i nižu emocionalnu samoefikasnost. Među vrijednostima najznačajnijom se pokazala tradicija koja je značajno doprinijela objašnjenju varijabli školskoga postignuća te sigurnost koja je značajno doprinijela objašnjenju emocionalne samoefikasnosti (pred)adolescenata. Doživljaj roditeljstva kao subjektivna procjena majki o njihovoj roditeljskoj kompetentnosti i zadovoljstvu roditeljstvom pokazao se važnim u objašnjenju akademske samoefikasnosti, ali samo kad je riječ o samoprocjeni zadovoljstva roditeljstvom. Dob majke bila je značajan prediktor jedino za socijalnu samoefikasnost adolescenata. Rezultati su pokazali da je postotak objašnjene varijance za većinu kriterijskih varijabli bio relativno skroman te je varirao od $3 \%$, koliko je iznosio za opći uspjeh, do $19 \%$, koliko je iznosio za akademsku samoefikasnost.

Tablica 5.

Rezultati regresijskih analiza (metoda forward stepwise) s varijablama samopoštovanja, samoefikasnosti i postignuća adolescenata kao kriterijima

\begin{tabular}{|c|c|c|c|c|c|c|}
\hline kriterij & korak & $\begin{array}{c}\text { varijable uključene } \\
\text { u model }\end{array}$ & $\beta$ & $R\left(R^{2}\right)$ & $\Delta R^{2}$ & $\begin{array}{c}F \\
(d f)\end{array}$ \\
\hline \multirow{2}{*}{ Opći uspjeh } & 1. & spol & $.17^{*}$ & $.17(.03)$ & & $\begin{array}{c}6.81^{*} \\
(1,232) \\
\end{array}$ \\
\hline & 2. & $\begin{array}{l}\text { spol } \\
\text { tradicija }\end{array}$ & $\begin{array}{l}.17^{*} \\
.15^{*}\end{array}$ & $.23(.05)$ & $.02^{*}$ & $\begin{array}{c}6.25^{*} \\
(2,231)\end{array}$ \\
\hline \multirow{3}{*}{ Matematika } & 1. & dob & $-.20^{*}$ & $.20(.04)$ & & $\begin{array}{c}9.69^{*} \\
(1,232)\end{array}$ \\
\hline & 2. & $\begin{array}{l}\text { dob } \\
\text { spol }\end{array}$ & $\begin{array}{l}-.25^{*} \\
.15^{*}\end{array}$ & $.25(.06)$ & $.02^{*}$ & $\begin{array}{c}7.53^{*} \\
(2,231)\end{array}$ \\
\hline & 3. & $\begin{array}{l}\text { dob } \\
\text { spol } \\
\text { tradicija }\end{array}$ & $\begin{array}{l}-.22^{*} \\
.15^{*} \\
.13^{*} \\
\end{array}$ & $.28(.08)$ & $.02^{*}$ & $\begin{array}{c}6.49^{*} \\
(3,230)\end{array}$ \\
\hline \multirow{2}{*}{ Hrvatski jezik } & 1. & spol & $.23^{*}$ & $.23(.05)$ & & $\begin{array}{c}13.15^{*} \\
(1,232) \\
\end{array}$ \\
\hline & 2. & $\begin{array}{l}\text { spol } \\
\text { tradicija }\end{array}$ & $\begin{array}{l}.23^{*} \\
.16^{*} \\
\end{array}$ & $.28(.08)$ & $.03^{*}$ & $\begin{array}{c}9.88^{*} \\
(2,231) \\
\end{array}$ \\
\hline \multirow{3}{*}{$\begin{array}{l}\text { Akademska } \\
\text { samoefikasnost }\end{array}$} & 1. & dob & $-.36^{*}$ & $.36(.13)$ & & $\begin{array}{c}34.94^{*} \\
(1,232)\end{array}$ \\
\hline & 2. & $\begin{array}{l}\text { dob } \\
\text { zadovoljstvo roditeljstvom }\end{array}$ & $\begin{array}{l}-.38^{*} \\
.19^{*} \\
\end{array}$ & $.41(.17)$ & $.04^{*}$ & $\begin{array}{l}23.39^{*} \\
(2,231) \\
\end{array}$ \\
\hline & 3. & $\begin{array}{l}\text { dob } \\
\text { zadovoljstvo roditeljstvom } \\
\text { spol }\end{array}$ & $\begin{array}{l}-.43^{*} \\
.19^{*} \\
.16^{*} \\
\end{array}$ & $.44(.19)$ & $.02^{*}$ & $\begin{array}{c}18.23^{*} \\
(3,230)\end{array}$ \\
\hline \multirow{2}{*}{$\begin{array}{l}\text { Emocionalna } \\
\text { samoefikasnost }\end{array}$} & 1. & spol & $-.19^{*}$ & $.19(.04)$ & & $\begin{array}{c}8.95^{*} \\
(1,232)\end{array}$ \\
\hline & 2. & $\begin{array}{l}\text { spol } \\
\text { sigurnost }\end{array}$ & $\begin{array}{l}-.19^{*} \\
.13^{*} \\
\end{array}$ & $.23(.06)$ & $.02^{*}$ & $\begin{array}{c}6.75^{*} \\
(2,231) \\
\end{array}$ \\
\hline $\begin{array}{l}\text { Socijalna } \\
\text { samoefikasnost }\end{array}$ & 1. & dob majke & $-.14^{*}$ & $.14(.02)$ & & $\begin{array}{c}4.66^{*} \\
(1,232) \\
\end{array}$ \\
\hline
\end{tabular}

${ }^{*} p<.05$. 


\section{Rasprava}

Rezultati istraživanja potvrdili su već poznate nalaze o razlikama između djevojaka i mladića u školskome postignuću, pri čemu su djevojke ostvarile bolji uspjeh iz Hrvatskoga jezika te bolji opći školski uspjeh, čime je potvrđena polazna hipoteza istraživanja. To je u skladu s rezultatima ranijih istraživanja (Jokić i RistićDedić, 2010; Koludrović i Kalebić Jakupčević, 2017), a upućuje na sustavno bolje školske rezultate djevojaka kad su oni izraženi školskim ocjenama. Različiti su razlozi u podlozi takvih rezultata, od onih socijalizacijskih prema kojima je sastavni dio rodno specifičnoga odgoja djevojaka veća usmjerenost na školske obveze i visoka očekivanja okoline od djevojaka kad je riječ o školskim postignućima, preko veće predanosti djevojaka školskim obvezama u odnosu na mladiće (Roviš i Bezinović, 2011), većega zadovoljstva odnosima s učenicima i nastavnicima (Ćoso, 2011; Koludrović i Kalebić Jakupčević, 2017), do više motivacije (Anderman i Anderman, 1999; Koludrović i Reić Ercegovac, 2013; Martin, 2011).

Rezultati u varijablama samopoštovanja i samoefikasnosti pokazali su da se mladići procjenjuju emocionalno samoefikasnijima te višega samopoštovanja $u$ odnosu na djevojke. Više samopoštovanje mladića u odnosu na djevojke često se potvrđuje u istraživanjima (Bleidorn i sur., 2016; Frost i McKelvie, 2004; Moksnes i Espnes, 2013; Quatman i Watson, 2001). Iako nema konačnoga odgovora na pitanje zašto je tomu tako, uzroke je moguće tražiti i u socijalizacijskim, ali i u biološkim čimbenicima. Naime, rezultati međukulturalnoga istraživanja Bleidorna i suradnika (2016) upućuju na mogućnost bioloških čimbenika koji bi bili odgovorni za takve konzistentne rodne razlike u samopoštovanju jer su utvrđene u gotovo svim kulturama te u različitim dobnim uzorcima, od ulaska u adolescenciju do odrasle dobi. Uz biološku osnovu koja nije dovoljno istražena, pretpostavlja se da razlikama u samopoštovanju pridonose i različiti odgojni utjecaji, rodne uloge i poticanje onih rodno specifičnih ponašanja kod djece koja se u konačnici manifestiraju i razlikama u samopoimanju djevojaka i mladića. Nadalje, utvrđene razlike u emocionalnoj samoefikasnosti, gdje su se mladići pokazali uspješnijima, moguće je pripisati višoj emocionalnoj stabilnosti muškaraca, što se pojavljuje već od adolescentske dobi (De Bolle i sur., 2015; McCrae i sur., 2002; sve prema Reić Ercegovac, Koludrović i sur., 2019).

Dobne razlike u mjerama postignuća, samopoštovanja i samoefikasnosti nisu zasebno testirane, ali su rezultati regresijskih analiza pokazali da je dob značajan (negativan) prediktor postignuća iz Matematike i akademske samoefikasnosti. Niži uspjeh iz Matematike u starijoj dobi dobro je dokumentiran ranijim istraživanjima (Koludrović i Kalebić Jakupčević, 2017; Reić Ercegovac i sur., 2019), dok je opadanje akademske samoefikasnosti, uzimajući u obzir raspon dobi sudionika, vjerojatno rezultat porasta školskih zahtjeva s dobi učenika (posebno između razredne i predmetne nastave, pa potom osnovne i srednje škole), kao i lošije školsko postignuće izraženo školskim ocjenama kod starijih u odnosu na mlađe učenike. 
Razlike u vrijednostima s obzirom na razinu obrazovanja majki upućuju na zaključak o većoj važnosti zadržavanja tradicionalnih odnosa u skupini majki sa srednjoškolskom razinom obrazovanja (Tablica 3.), što je u skladu s polaznim očekivanjima. Majke s višom razinom obrazovanja manje vrednuju te tradicionalne vrijednosti. Povezanost između dobi i vrijednosti pokazala je da mlađe majke, u odnosu na starije, više vrednuju samousmjeravanje i konformizam. Povezanost između samousmjeravanja $\mathrm{i}$ dobi je sukladna rezultatima ranijih istraživanja (Robinson, 2013), a odražava veću sklonost mlađih pojedinaca fleksibilnosti i promjenama, kreativnosti i osobnom rastu. S druge strane, odnos između dobi i konformizma suprotan je polaznim očekivanjima, ali i rezultatima ranijih istraživanja koja upućuju na pozitivnu povezanost dobi i tradicionalnih vrijednosti što se obično pripisuje adaptivnim procesima i prilagodbama u starijih ljudi koje su povezane $\mathrm{s}$ višom dobrobiti (Robinson, 2013). Iako relativno niska, negativna povezanost dobi i konformizma možda dijelom odražava proces „retradicionalizacije“ u suvremenom hrvatskom društvu (Ilišin i Gvozdanović, 2016) koja uključuje, između ostaloga, socijalni konformizam i prvenstvo kolektiviteta nad pojedincem. U ovome su se istraživanju upravo vrijednosti zadržavanja tradicionalnih odnosa majki pokazale značajnim prediktorima školskoga postignuća i emocionalne samoefikasnosti djece, pri čemu je za sve tri mjere postignuća značajan prediktor bila tradicija, a za emocionalnu samoefikasnost sigurnost. Tradicija i sigurnost, kao konzervativne vrijednosti, važnije su u sredinama koje visoko vrednuju trud i samokontrolu, ali i grupnu naspram individualne dobrobiti, što je jedna od glavnih značajki kolektivističkih kultura. Istraživanja u kojima je propitivan odnos kolektivističkih naspram individualističkih kultura i odgovarajućih roditeljskih ponašanja uputila su na negativnu povezanost između kolektivističkih vrijednosti majke i indukcije, odnosno negativnu povezanost između socijalne harmonije i psihološke kontrole (Shuster i sur., 2012). U tome je istraživanju psihološka kontrola kao nepoželjan oblik kontrole $\mathrm{u}$ roditeljskome ponašanju bila povezana s višom agresivnošću, dok je indukcija kao poželjno roditeljsko postupanje bila povezana sa smanjenom agresivnošću adolescenata (Shuster i sur., 2012). Indukcija se također pokazala značajnim prediktorom školskih postignuća adolescenata, a kontrola ponašanja značajnim prediktorom samoefikasnosti i usmjerenosti na postignuće (Ingoldsby i sur., 2004). Potonjemu donekle idu u prilog i rezultati ovoga istraživanja o odnosu sigurnosti, tradicije, postignuća i samoefikasnosti jer je opravdano pretpostaviti da majke koje visoko vrednuju konzervativne vrijednosti prakticiraju u svojemu roditeljstvu i strožu kontrolu ponašanja. Ipak, ovim istraživanjem nisu bila zahvaćena konkretna roditeljska ponašanja pa bi te pretpostavke valjalo dodatno istražiti. Moguće je da su se u ovome istraživanju konzervativne vrijednosti pokazale važnima za školsko postignuće jer te vrijednosti promoviraju skladne socijalne odnose, izbjegavanje konflikata i narušavanja normi (Schwartz, 2012), a što je u našemu odgojno-obrazovnom sustavu još uvijek visoko cijenjeno i često pridonosi i boljemu školskom uspjehu učenika koji u svojemu ponašanju manifestiraju upravo takve vrijednosti. 
Iako istraživanje nije uputilo na značajan doprinos vrijednosti majki objašnjenju razlika u akademskoj i socijalnoj samoefikasnosti, sigurnost kao vrijednost značajno je doprinijela objašnjenju razlika u emocionalnoj samoefikasnosti (pred)adolescenata. Emocionalna se samoefikasnost primarno odnosi na sposobnost reguliranja negativnih emocija (Vulić Prtorić i sur., 2006) pa je moguće da majke koje visoko vrednuju sigurnost stvaraju obiteljsko ozračje u kojemu, s ciljem očuvanja stabilnosti i sigurnosti zajednice, djeca uspješnije razvijaju mehanizme kontroliranja „negativnih” emocija. U prilog tim rezultatima govore i nalazi o boljoj emocionalnoj samokontroli djece iz dominantno kolektivističkih kultura (Xu i sur., 2005) jer se u takvim kulturama njeguju upravo tradicionalne i konzervativne vrijednosti, a kultura oblikuje roditeljske kognicije koje određuju roditeljska ponašanja (Bornstein, 2012).

Rezultati ovoga istraživanja upućuju na mogućnost da su vrijednosti zadržavanja tradicionalnih odnosa u podlozi onih roditeljskih ponašanja koje je moguće povezati s boljim školskim uspjehom i emocionalnom samoefikasnošću adolescenata. Slično tomu, Aavik i suradnici (2006) utvrdili su značajnu pozitivnu povezanost između postavljanja granica i konzervatizma kao roditeljske vrijednosti te negativnu povezanost između postavljanja granica i hedonizma. Budući da je postavljanje granica jedna od ključnih značajki optimalnih roditeljskih stilova, može se zaključiti da su roditelji više izraženih tradicionalnih vrijednosti efikasniji u postavljanju granica, što u konačnici ima pozitivne učinke na školsko postignuće i samoefikasnost djece. Te bi pretpostavke vrijedilo istražiti u budućim istraživanjima.

Konačno, rezultati su uputili na značajnu povezanost vrijednosti i doživljaja majčinstva, i to posebno u dijelu roditeljske kompetentnosti. Majke koje više vrednuju moć, postignuće te sve tri konzervativne vrijednosti (sigurnost, tradiciju i konformizam) ujedno se procjenjuju kompetentnijima u svojoj roditeljskoj ulozi pa je moguće da je dio doprinosa vrijednosti objašnjenju školskoga postignuća i samoefikasnosti adolescenata posredovan i subjektivnom procjenom majki o njihovoj roditeljskoj kompetentnosti. Naime, istraživanja pokazuju da je percipirana kompetentnost u roditeljskoj ulozi često dobar prediktor stvarnih roditeljskih kompetencija (Coleman i Karraker, 1998; Jones i Prinz, 2005; Sanders i Woolley, 2005; Sevigny i Loutzenhiser, 2010; Teti i Gelfand, 1991). Kad je riječ o zadovoljstvu roditeljstvom, jedinim značajnim korelatom među vrijednostima pokazao se hedonizam, i to negativno, što znači da su majke koje više vrednuju hedonizam zapravo manje zadovoljne svojim roditeljstvom. To ne iznenađuje jer je riječ o vrijednosti koja se odnosi na zadovoljenje vlastitih želja, zadovoljstvo i uživanje, a čemu roditeljstvo može (ali i ne mora) biti prepreka.

\section{Zaključak}

Prije zaključka valja se osvrnuti na nedostatke provedenoga istraživanja. Jedan od njih odnosi se na uključenost samo majki, a ne i očeva čiji bi doprinos ispitanim 
aspektima razvojnih ishoda adolescenata također trebalo istražiti. Ipak, istraživanja sustavno pokazuju da su majke međukulturalno u većini slučajeva primarni skrbnici djece te da još uvijek provode značajno više vremena u interakciji s djetetom u odnosu na oca (Altenburger i sur., 2018; Geary, 2000; Parke i sur., 2005). Nadalje, jedna od korištenih mjera imala je nešto nižu pouzdanost (socijalna samoefikasnost), no riječ je o još uvijek prihvatljivoj vrijednosti, a skala je i ranije korištena u mnogobrojnim istraživanjima na uzorcima djece i adolescenata te je uglavnom pokazala dobre metrijske značajke. Tomu treba dodati da su kod provjere strukture nekih podljestvica izračunani parametri prikladnosti modela pokazali različite vrijednosti, pri čemu je dio njih uputio na dobru prikladnost modela, a dio nije. Ipak, vodeći se i parametrima pouzdanosti, korištene su strukture za koje je, uz prihvatljivu pouzdanost, barem dio parametara pokazao dobro pristajanje podataka pretpostavljenim modelima.

Unatoč navedenim nedostacima istraživanje je pokazalo da vrijednosti majke doprinose školskomu postignuću (pred)adolescenata, kao i nekim aspektima samoefikasnosti, pri čemu su se relevantnima pokazale vrijednosti zadržavanja tradicionalnih odnosa. Zadovoljstvo roditeljstvom, kao komponenta doživljaja roditeljstva, pokazalo se prediktivnim za akademsku samoefikasnost djece, što može imati značajnih posljedica i na školsko postignuće jer je akademska samoefikasnost jedan od najznačajnijih prediktora školskoga uspjeha (Bandura, 1993; Honicke i Broadbent, 2016; Koludrović i sur., 2014). U budućim bi istraživanjima valjalo provjeriti pretpostavku o roditeljskim (majčinskim) ponašanjima kao posredniku između vrijednosti i akademskih ishoda (pred)adolescenata.

\section{Literatura}

Aavik, A., Aavik, T. i Kõrgesaar, J. (2006). Parenting practices and personal values: Comparison between parents of institutionalized and non-institutionalized adolescents. Trames, 10(1), 44-56.

Altenburger, L. E., Schoppe-Sullivan, S. J. i Dush, C. M. K. (2018). Associations between maternal gatekeeping and fathers' parenting quality. Journal of Child and Family Studies, 27(8), 2678-2689. https://doi.org/10.1007/s10826-018-1107-3

Anderman, L. H. i Anderman, E. M. (1999). Social predictors of changes in students' achievement goal orientations. Contemporary Educational Psychology, 25, 21-37.

Armum, P. i Chellappan, K. (2016). Social and emotional self-efficacy of adolescents: Measured and analysed interdependencies within and across academic achievement level. International Journal of Adolescence and Youth, 21(3), 279-288. https://doi.org/10.1080/02673843.2015.1067894

Bacchini, D. i Magliulo, F. (2003). Self-image and perceived self-efficacy during adolescence. Journal of Youth and Adolescence, 32, 337-349. https://doi.org/10.1023/ a:1024969914672 
Bandura, A. (1993). Perceived self-efficacy in cognitive development and functioning. Educational Psychologist, 28(2), 117-148. https://doi.org/10.1207/s15326985ep2802_3

Bleidorn, W., Arslan, R. C., Denissen, J. J. A., Rentfrow, P. J., Gebauer, J. E., Potter, J. i Gosling, S. D. (2016). Age and gender differences in self-esteem: A cross-cultural window. Journal of Personality and Social Psychology, 111(3), 396-410. https://doi.org/10.1037/pspp0000078

Bornstein, M. H. (2012). Cultural approaches to parenting. Parenting, Science and Practice, 12(2-3), 212-221. https://doi.org/10.1080/15295192.2012.683359

Carvajal, S. C., Clair, S. D., Nash, S. G. i Evans, R. I. (1998). Relating optimism, hope and selfesteem to social influences in deterring substance use in adolescents. Journal of Social and Clinical Psychology, 17, 443-465. https://doi.org/10.1521/jscp.1998.17.4.443

Coleman, P. K. i Karraker, K. H. (1998). Self-Efficacy and parenting quality: Findings and future applications. Developmental Review, 18(1), 47-85. https://doi.org/10.1006/drev. 1997.0448

Ćoso, B. (2011). Strah od škole i zadovoljstvo učiteljima. Napredak: Časopis za pedagogijsku teoriju i praksu, 153(3-4), 443-461.

Darling, N. i Steinberg, L. (1993). Parenting style as context: An integrative model. Psychological Bulletin, 113, 487-496. https://doi.org/10.1037/0033-2909.113.3.487

Erikson, E. H. (1980). Identity and the life cycle. Norton.

Ferić, I. (2007). Univerzalnost sadržaja i strukture vrijednosti: Podaci iz Hrvatske. Društvena istraživanja, 16(1-2), 3-26.

Frost, J. i McKelvie, S. (2004). Self-esteem and body satisfaction in male and female elementary school, high school, and university students. Sex Roles, 51(1-2), 45-54. https://doi.org/10.1023/b:sers.0000032308.90104.c6

Geary, D. C. (2000). Evolution and proximate expression of human paternal investment. Psychological Bulletin, 126, 55-77. https://doi.org/10.1037/0033-2909.126.1.55

Gibaud-Wallston, J. i Wandersman, L. P. (1978). Development and utility of the Parenting Sense of Competence Scale. Proceedings of the 86th Annual Convention of the American Psychological Association, August - September 1978. American Psychological Association.

Granic, I. i Patterson, G. R. (2006). Toward a comprehensive model of antisocial development: A dynamic systems approach. Psychological Review, 113, 101-131. https://doi.org/10.1037/0033-295x.113.1.101

Gravetter, F. i Wallnau, L. (2014). Essentials of statistics for the behavioral sciences (8th ed.). Wadsworth.

Honicke, T. i Broadbent, J. (2016). The influence of academic self-efficacy on academic performance: A systematic review. Educational Research and Reviews, 17, 63-84. https://doi.org/10.1016/j.edurev.2015.11.002 
Huang, C. (2013). Gender differences in academic self-efficacy: A meta-analysis. European Journal of Psychology of Education, 28(1), 1-35. https://doi.org/10.1007/s10212-0110097-y

Humphrey, N., Charlton, J. P. i Newton, I. (2004). The developmental roots od disaffection? Educational Psychology, 24(5), 579-594. https://doi.org/10.1080/0144341042000262926

Ilišin, V. i Gvozdanović, A. (2016). Struktura i dinamika vrijednosti mladih u Hrvatskoj. U: Sekulić, D. (Ur.), Vrijednosti u hrvatskom društvu (str. 169-197). Centar za demokraciju i pravo Miko Tripalo, Zagreb.

Inchley, J., Currie, D., Young, T., Samdal, O., Torsheim, T., Augustson, L., Mathison, F., Aleman-Diaz, A., Molcho, M., Weber, M. W. i Barnekow, V. (Ur.) (2016). Growing up unequal gender and socioeconomic differences in young people's health and well-being: Health behaviour in school-aged children study. International report from the 2013/2014 survey. World Health Organization.

Ingoldsby, B., Schvaneveldt, P., Supple, A. i Bush, K. (2004). The relationship between parenting behaviors and adolescent achievement and self-efficacy in Chile and Ecuador. Marriage \& Family Review, 35(3), 139-159. https://doi.org/10.1300/j002v35n03_08

Jenkins, S. R., Goodness, K. i Buhrmester, D. (2002). Gender differences in early adolescents' relationship qualities, self-efficacy, and depression symptoms. The Journal of Early Adolescence, 22(3), 277-309. https://doi.org/10.1177/02731602022003003

Jiang, X. X., Huebner, E. E. i Hills, K. J. (2013). Parent attachment and early adolescents' life satisfaction: The mediating role of hope. Psychology in Schools, 50, 340-352. https://doi.org/10.1002/pits.21680

Johnston, C. i Mash, E. J. (1989). A measures of parenting satisfaction and efficacy. Journal of Clinical Child Psychology, 18, 167-175.

Jokić, B. i Ristić Dedić, Z. (2010). Razlike u školskom uspjehu učenika trećih i sedmih razreda osnovnih škola u Republici Hrvatskoj s obzirom na spol učenika i obrazovanje roditelja: Populacijska perspektiva. Revija za socijalnu politiku, 17(3), 345-362

Jones, T. L. i Prinz, R. J. (2005). Potential roles of parental self-efficacy in parent and child adjustment: A review. Clinical Psychology Review, 25(3), 341-363. https://doi.org/10. 1016/j.cpr.2004.12.004

Kasser, T., Koestner, R. i Lekes, N. (2002). Early family experiences and adult values: A 26year, prospective longitudinal study. Personality and Social Psychology Bulletin, 28(6), 826-835. https://doi.org/10.1177/0146167202289011

Kendler, K., Gardner, C. O. i Prescot, C. A. (1998). A population-based twin srudy od selfesteem and gender. Psychological Medicine, 28, 1403-1409. https://doi.org/10.1017/ s0033291798007508

Keresteš, G., Rezo, I. i Ajduković, M. (2019). Links between attachment to parents and internalizing problems in adolescence: The mediating role of adolescents' personality. Current Psychology. https://doi.org/10.1007/s12144-019-00210-3 
Kohn, M. L. (1977). Class and conformity: A study in values (2nd ed.). University of Chicago Press.

Koludrović, M. i Reić Ercegovac, I. (2013). Motivacija i školski uspjeh: Dobne i spolne razlike u ciljnim orijentacijama. Napredak: Časopis za pedagogijsku teoriju i praksu, 154(4), 493-509.

Koludrović, M., Bubić, A. i Reić Ercegovac, I. (2014). Self-efficacy and achievement goals as predictors of high-school students' academic performance. Školski vjesnik, 64(4), 579-602.

Koludrović, M. i Kalebić Jakupčević, K. (2017). Odnos razrednog ozračja i školskog uspjeha učenika osnovnoškolske dobi. Školski vjesnik: Časopis za pedagoška i školska pitanja, 66(4), 557-572.

Lacković Grgin, K. (1994). Samopoimanje mladih. Naklada Slap.

Lippold, M. A., Duncan, L. G., Coatsworth, J. D., Nix, R. L. i Greenberg, M. T. (2015). Understanding how mindful parenting may be linked to mother-adolescent communication. Journal of Youth and Adolescence, 44, 1663-1673. https://doi.org/10. 1007/s10964-015-0325-X

Luster, T., Rhoades, K. i Haas, B. (1989). The relation between parental values and parenting behaviour: A test of Kohn hypothesis. Journal of Marriage and the Family, 51, 139147. https://doi.org/10.2307/352375

Ljubetić, M., Reić Ercegovac, I. i Mandarić Vukušić, A. (2018). Irresponsible/unmindful parenting: An empire for the media. U: J. Lepičnik Vodopivec, L. Jančec i T. Štemberger (Ur.), Implicit Pedagogy for Optimized Learning in Contemporary Education (str. 270-289). IGI Global. https://doi.org/10.4018/978-1-5225-57999.ch014

Maccoby, E. E. (2000). Parenting and its effects on children: On reading and misreading behavior genetics. Annual Review of Psychology, 51, 1-27. https://doi.org/10.1146/ annurev.psych.51.1.1

Mandarić Vukušić, A. (2018). Self-evaluation of parental competence - differences between parents with pedagogical and non-pedagogical professions. World Journal of Education, 8(2), 1-9. https://doi.org/10.5430/wje.v8n2p1

Martin, A. J. (2011). School motivation of boys and girls: Differences of degree, differences of kind, or both? Australian Journal of Psychology, 56(3), 133-146. https://doi.org/10. 1080/00049530412331283363

Martinez, I., Garcia, F., Veiga, F., Garcia, O. F., Rodrigues, Y. i Serra, E. (2020). Parenting styles, internalization of values and self-esteem: A cross-cultural study in Spain, Portugal and Brazil. International Journal of Environmental Research and Public Health, 17(7), 2370. https://doi.org/10.3390/ijerph17072370

Moksnes, U. K. i Espnes, G. A. (2013). Self-esteem and life satisfaction in adolescents-gender and age as potential moderators. Quality Life Research, 22(10), 2921-2928. https://doi.org/10.1007/s11136-013-0427-4 
Musić, H., Mulaosmanović, N. i Kajtaz, E. (2014). Spolne razlike u samopoimanju srednjoškolaca. Educa, 7, 65-75.

Parent, J., McKee, L. G., Rough, J. N. i Forehand, R. (2016). The association of parent mindfulness with parenting and youth psychopathology across three developmental stages. Journal of Abnormal Child Psychology, 44, 191-202. https://doi.org/10.1007/ s10802-015-9978-x

Parke, R. D., Dennis, J., Flyr, M. L., Morris, K. L., Leidy, M. S. i Schofield, T. J. (2005). Fathers: Cultural and ecological perspectives. U: L. Luster i L. Okagaki (Ur.), Parenting: An ecological perspective. 2nd ed. (str. 103-144). Erlbaum.

Quatman, T. i Watson, C. (2001). Gender differences in adolescent self-esteem: An exploration of domains. The Journal of Genetic Psychology, 162, 93-117. https://doi.org/10.1080/00221320109597883

Reić Ercegovac, I. i Koludrović, M. (2010). Akademska samoefikasnost i školski uspjeh adolescenata. Pedagogijska istraživanja, 7(1), 111-128.

Reić Ercegovac, I. i Penezić, Z. (2012). Subjektivna dobrobit bračnih partnera prilikom tranzicije u roditeljstvo. Društvena istraživanja, 2(116), 341-361. https://doi.org/10. 5559/di.21.2.03

Reić Ercegovac, I., Koludrović, M. i Mišurac, I. (2019). The contribution of the mathematics selfconcept and subjective value of mathematics to mathematical achievement. Zbornik Instituta za pedagoška istraživanja, 51, 162-197. https://doi.org/10.2298/ZIPI1901162R

Reić Ercegovac, I., Maglica, T. i Ljubetić, M. (2019). Odnos samopoimanja, subjektivne dobrobiti i školskog uspjeha tijekom adolescencije. U: I. Klasnić (Ur.), Zbornik radova međunarodne znanstveno-umjetničke konferencije Contemporary Themes in Education - CTE Pedagogy and Psychology: From Amending Drawbacks to Enhancing Personal Strengths and Virtues (str. 221-243). Sveučilište u Zagrebu, Učiteljski fakultet.

Robins, R. W. i Trzesniewski, K. H. (2005). Self-esteem development across the life-span. Current Directions in Psychological Science, 14(3), 158-162. https://doi.org/10. 1111/j. 0963-7214.2005.00353.x

Robins, R. W., Trzesniewski, K. H., Tracy, J. L., Gosling, S. D. i Potter, J. (2002). Global self-esteem across the life span. Psychology and Aging, 17(3), 423-434. https://doi.org/ 10. $1037 / 0882-7974.17 .3 .423$

Robinson, O. C. (2013). Values and adult age: Findings from two cohorts of the European Social Survey. European Journal of Ageing, 10(1), 11-23. https://doi.org/10.1007/ s10433-012-0247-3

Rosenberg, M. (1965). Society and the adolescent self-image. Princeton University Press.

Roviš, D. i Bezinović, P. (2011). Vezanost za školu - analiza privrženosti školi i predanosti školskim obvezama kod srednjoškolaca. Sociologija i prostor: Časopis za istraživanje prostornoga i sociokulturnog razvoja, 49(2), 185-208.

Rudan, V. (2004). Normalni adolescentni razvoj. Medix, 10(52), 36-39. 
Sanders, M. R. i Woolley, M. L. (2005). The relationship between maternal self-efficacy and parenting practices: Implications for parent training. Child: Care, Health and Development, 31, 65-73. https://doi.org/10.1111/j.1365-2214.2005.00487.x

Schwartz, S. (1992). Universals in the content and structure of values: Theoretical advances and empirical tests in 20 Countries. Advances in Experimental Social Psychology, 25, 1-65. https://doi.org/10.1016/s0065-2601(08)60281-6

Schwartz, S. H. (2012). An overview of the Schwartz theory of basic values. Online Readings in Psychology and Culture, 2(1). https://doi.org/10.9707/2307-0919.1116

Sevigny, P. R. i Loutzenhiser, L. (2010). Predictors of parenting self-efficacy in mothers and fathers of toddlers. Child: Care, Health, Development, 36, 179-189. https://doi.org/10.1111/j.1365-2214.2009.00980.x

Shuster, M. M., Li, Y. i Shi, J. (2012). Maternal cultural values and parenting practices: Longitudinal associations with Chinese adolescent's aggression. Journal of Adolescence, 35, 345-355. https://doi.org/10.1016/j.adolescence.2011.08.006

Sorić, I. i Vulić-Prtorić, A. (2006). Percepcija roditeljskoga ponašanja, školska samoefikasnost i kauzalne atribucije u kontekstu samoregulacije učenja. Društvena istraživanja, 4-5(84-85), 773-797.

Sroufe, L. A., Egeland, B., Carlson, E. A. i Collins, W. A. (2005). The development of the person: The Minnesota study of risk and adaptation from birth to adulthood. Guilford Press.

Teti, D. M. i Gelfand, D. M. (1991). Behavioural competence among mothers of infants in the first year: The mediational role of maternal self-efficacy. Child Development, 62(5), 918-929. https://doi.org/10.2307/1131143

Tudge, J., Hogan, D., Lee, S., Tammeveski, P., Meltsas, M., Kulakova, N., Snezhkova, I. i Putnam, S. (1999). Cultural heterogeneity: Parental values and beliefs and their reschoolers' activities in the United States, South Korea, Russia and Estonia. U: A. Goncu (Ur.), Children's engagement in the world (str. 62-96). Cambridge University Press.

Vaillant, G. E. (2002). Aging well. Little, Brown and Company.

Vulić Prtorić, A., Sorić, I., Kramar, V. i Macuka, I. (2006). Upitnik samoefikasnosti za djecu - SEQ-C. U: V. Ćubela Adorić, A. Proroković, Z. Penezić i I. Tucak (Ur.), Zbirka psihologijskih skala i upitnika: Svezak 3 (str. 87-92). Sveučilište u Zadru.

Xu, Y., Farver, J., Zhang, Z., Zeng, Q., Yu, L. i Cai, B. (2005). Mainland Chinese Parenting Styles and Parent-Child Interaction. International Journal of Behavioral Development, 29, 524-531. https://doi.org/10.1177\%2F01650250500147121 


\title{
Values and Subjective Experience of Motherhood as Predictors of Self- Esteem, Self-Efficacy and School Achievement of (Pre)Adolescents
}

\begin{abstract}
The theoretical framework of this paper is the theory of value contents and structure and the model of parenting experience as a starting point for researching parental influences on the developmental outcomes of adolescents. The aim of the research was to examine the relationship between the universal values of mothers and the subjective experience of motherhood and self-esteem, selfefficacy and school achievement of (pre)adolescents. A total of 234 mother-child dyads participated in the research, and the following self-assessment questionnaires and scales were used: General Data Questionnaires for mother and adolescents, Self-Efficiency Questionnaire for children, Self-Esteem Scale, Life Values Questionnaire and Parental Sense of Competence Questionnaire. The results confirmed some expected gender differences in adolescents, as well as differences in mothers' values with respect to their age and level of education. Subjective assessment of maternal competence was significantly correlated with values of achievement, power, and triad of conservative values. Regression analyses showed that a smaller portion of the variance of self-esteem, self-efficacy and achievement of (pre)adolescents can be attributed to the values of the mother, with the most important role being conservative values.
\end{abstract}

Keywords: values, parenthood, (pre)adolescence, self-esteem, self-efficacy, school achievement

Primljeno: 14. 6. 2020. 